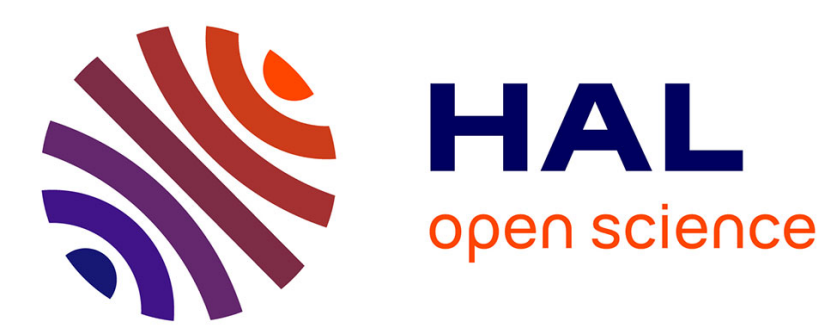

\title{
Revision of the upper Cretaceous rudists from Northwestern Peru.
}

\author{
Jean Philip, Etienne Jaillard
}

\section{To cite this version:}

Jean Philip, Etienne Jaillard. Revision of the upper Cretaceous rudists from Northwestern Peru.. Journal of South American Earth Sciences, 2004, 17, pp.39-48. hal-00101741

\section{HAL Id: hal-00101741 \\ https://hal.science/hal-00101741}

Submitted on 28 Sep 2006

HAL is a multi-disciplinary open access archive for the deposit and dissemination of scientific research documents, whether they are published or not. The documents may come from teaching and research institutions in France or abroad, or from public or private research centers.
L'archive ouverte pluridisciplinaire HAL, est destinée au dépôt et à la diffusion de documents scientifiques de niveau recherche, publiés ou non, émanant des établissements d'enseignement et de recherche français ou étrangers, des laboratoires publics ou privés. 


\title{
REVISION OF THE UPPER CRETACEOUS RUDISTS FROM NORTHWESTERN PERU
}

\author{
Jean PHILIP (1) and Etienne JAILLARD (2) \\ (1) Centre de Sédimentologie-Paléontologie, Université de Provence, 3 Place Victor Hugo, \\ 13331 Marseille Cedex 3, France. email: jphilip@ univ-mrs.fr \\ (2) IRD-LGCA, Maison des Géosciences, BP 53, 38041 Grenoble cedex 09, France. \\ email: Etienne.Jaillard@ujf-grenoble.fr
}

KEY WORDS: Rudists, Upper Cretaceous, Palaeobiogeography, Peru

\begin{abstract}
Revision of the Upper Cretaceous of northwestern Peru led to new discoveries of rudists and allowed to specify their taxonomy and stratigraphic repartition. Different species have been identified: Biradiolites cf. jamaicensis Trechmann 1924, Radiolites cf. macroplicatus Whitfield 1897, Praebarrettia sparcilirata (Whitfield, 1897) of Late Campanian age, Macgillavryia nicholasi (Whitfield, 1897), of "Middle" to Late Maastrichtian age. During Campanian and Maastrichtian times, rudists of Peru show palaeobiogeographic affinities with those of the Mexican and Caribbean domains. A palaeogeographic route for rudist migrations probably existed at that time along the Caribbean arc and the Curaçao-Ecuador coastline.
\end{abstract}

\section{Introduction}

While the earliest mention of rudists in South America was by d'Orbigny (1842), the first descriptions of Upper Cretaceous rudists from Peru were provided by Gerth (1928) and Olsson $(1934,1944)$. A recent stratigraphic revision of the Upper Cretaceous of northwestern Peru and southwest Ecuador (Jaillard et al., 1998; 2003) has resulted in the discovery of wellpreserved rudists and allowed them to be placed in their stratigraphical context.

The aim of this paper is to present a revision of the Upper Cretaceous rudists from northwestern Peru, in order to examine the palaeobiogeographic relationships of this area, with both the Caribbean and Central America Provinces during the Campanian and the Maastrichtian.

\section{Geological setting}

In northwestern Peru (Fig. 1), outcrops of Campanian and Maastrichtian sediments occur in elongated SSW-NNE trending forearc basins, presently located south of the AmotapeTahuin Paleozoic basement and west of the mid-Cretaceous Celica-Lancones Basin.

Rudist-bearing beds are well exposed in the La Tortuga section, which crops out south of the Paita town, and in the Monte Grande area, located east of Talara (Fig. 1).

In the Paita area, following Olsson (1944), Fisher (1956) and Alemán (1999), Jaillard et al. $(1998 ; 2003)$ and Taipe et al. (2000) subdivided the Campanian-Maastrichtian interval into three Formations, which are from base to top: - the La Mesa Formation, - the La Tortuga For- 
mation, - the Cenizo Formation. The respective ages of these formations have been established on the basis of ammonite and inoceramid records (Jaillard et al., 2003).

Rudists occur in the middle and upper members of the La Mesa Formation, in the middle unit of the La Tortuga Formation, and in the Cenizo Formation, particularly in the upper part of the latter.

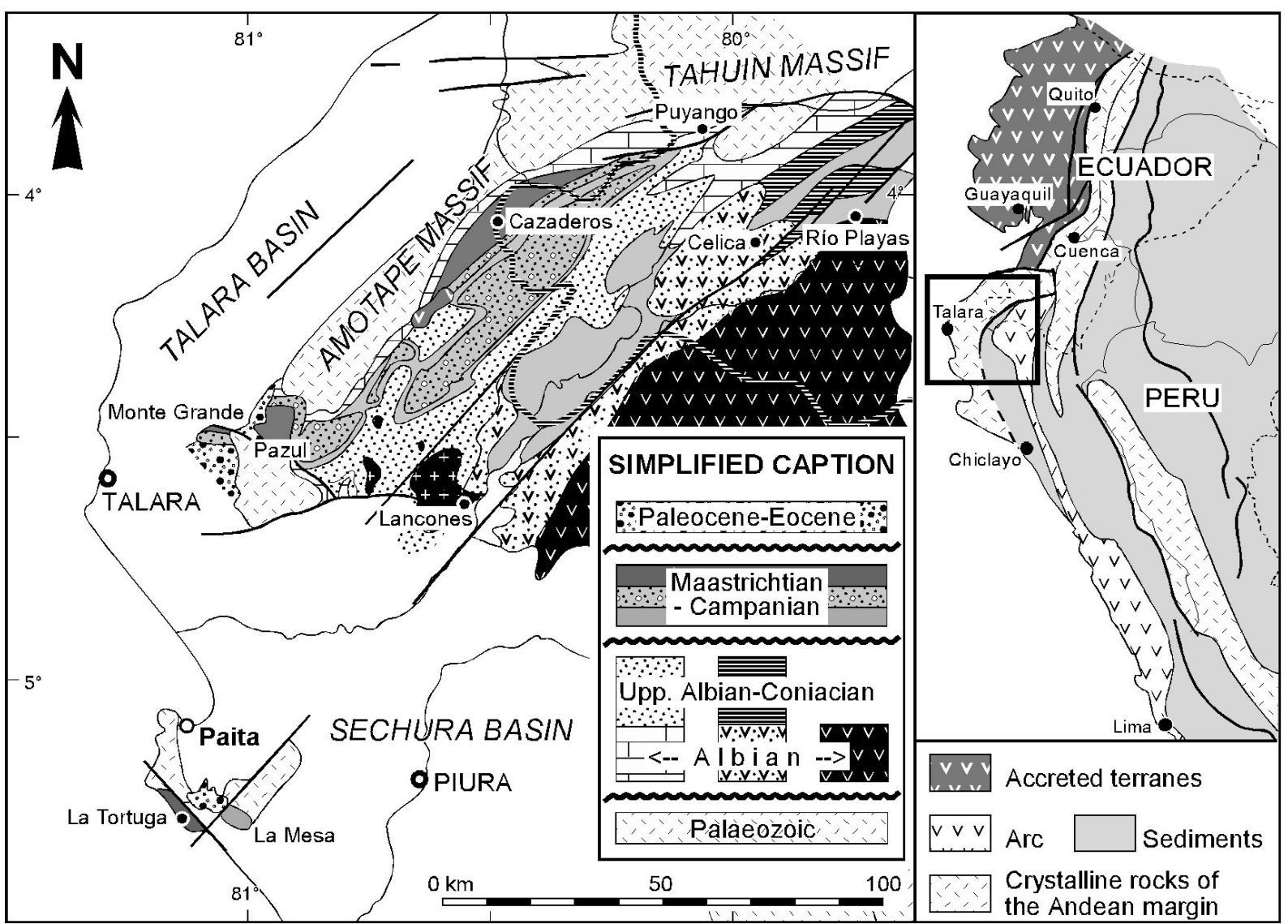

Figure 1. Location of the studied sections and of the main localities cited in the text.

\section{Stratigraphy}

\subsection{La Mesa Formation.}

In the La Mesa section (Fig. 2), located west of Cerro La Mesa, the La Mesa Formation unconformably rests upon the Paleozoic basement.

The Lower Member is made of transgressive facies bearing rounded bioclasts and oyster debris, followed by an alternation of shales and sandstones corresponding to an open shelf environment.

The Middle Member is carbonate dominated and represents the upper part of a transgressive-regressive sequence. It is formed by shelf limestones rich in rudists (Radiolitids), corals, and gastropods (Actaeonella). Rudist-rich floatstones and rudstones are well represented in the upper part of this member. In these facies, rudists are generally crushed. However we have identified numerous fragments of conical depressed right valves, bearing subpolygonal and reticulate cell structures, and bifurcated vessels on the commissural surface, attributed with doubts to the genus Macgillavryia. Gerth (1928), cited Praebarrettia peruviana from this Middle Member, but this was not found by us. 


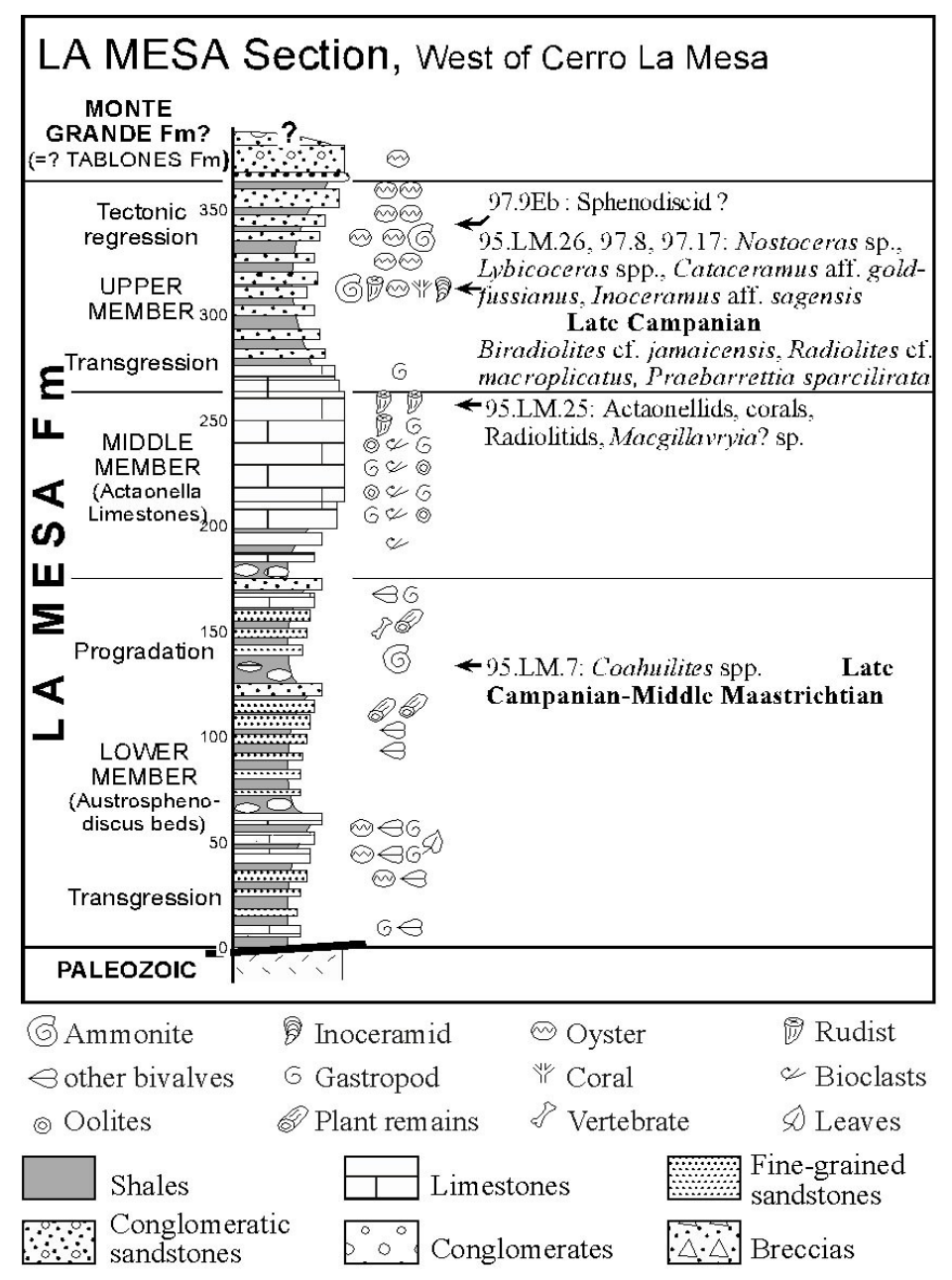

Figure 2. Section of the La Mesa Formation (West of Cerra la Mesa, Paita area), and location of rudists. Ammonites and inoceramids are from Jaillard et al. (2003) and Bengtson (written comm.).

The Upper Member is represented by an alternation of shales and sandstones bearing numerous inoceramids and rudists, associated with ammonites, corals, bivalves and echinoids. We have determined from this member: Praebarrettia sparcilirata (Whitfield), Radiolites cf. macroplicatus Whitfield, and Biradiolites cf. jamaicensis Trechmann. Ammonites and inoceramids (Fig. 2) suggest an Upper Campanian age for the Upper Member.

\subsection{La Tortuga Formation.}

In the La Tortuga section (Fig. 3) located along the shore (La Tortuga, Cenizo and Perico beaches), rudists occur in the Middle Unit of the La Tortuga Formation (Tortuga beds of Olsson, 1944) and in the upper part of the Cenizo Formation, which corresponds to the "Radiolites sandstones" of Olsson (1944).

The lower and upper parts of the $3500 \mathrm{~m}$ thick La Tortuga Formation are dominated by coarse-grained alluvial-fan breccias, intercalated with fan-delta breccias and shoreface sandstones. The Lower Breccia evolves toward a transgressive-regressive cycle, the maximum flooding of which is represented by the shaly marine middle unit (Tortuga beds). The latter contains ammonites (Sphenodiscus sp.), bivalves and the rudist Macgillavryia. This middle unit should be ascribed to the Lower Maastrichtian. 


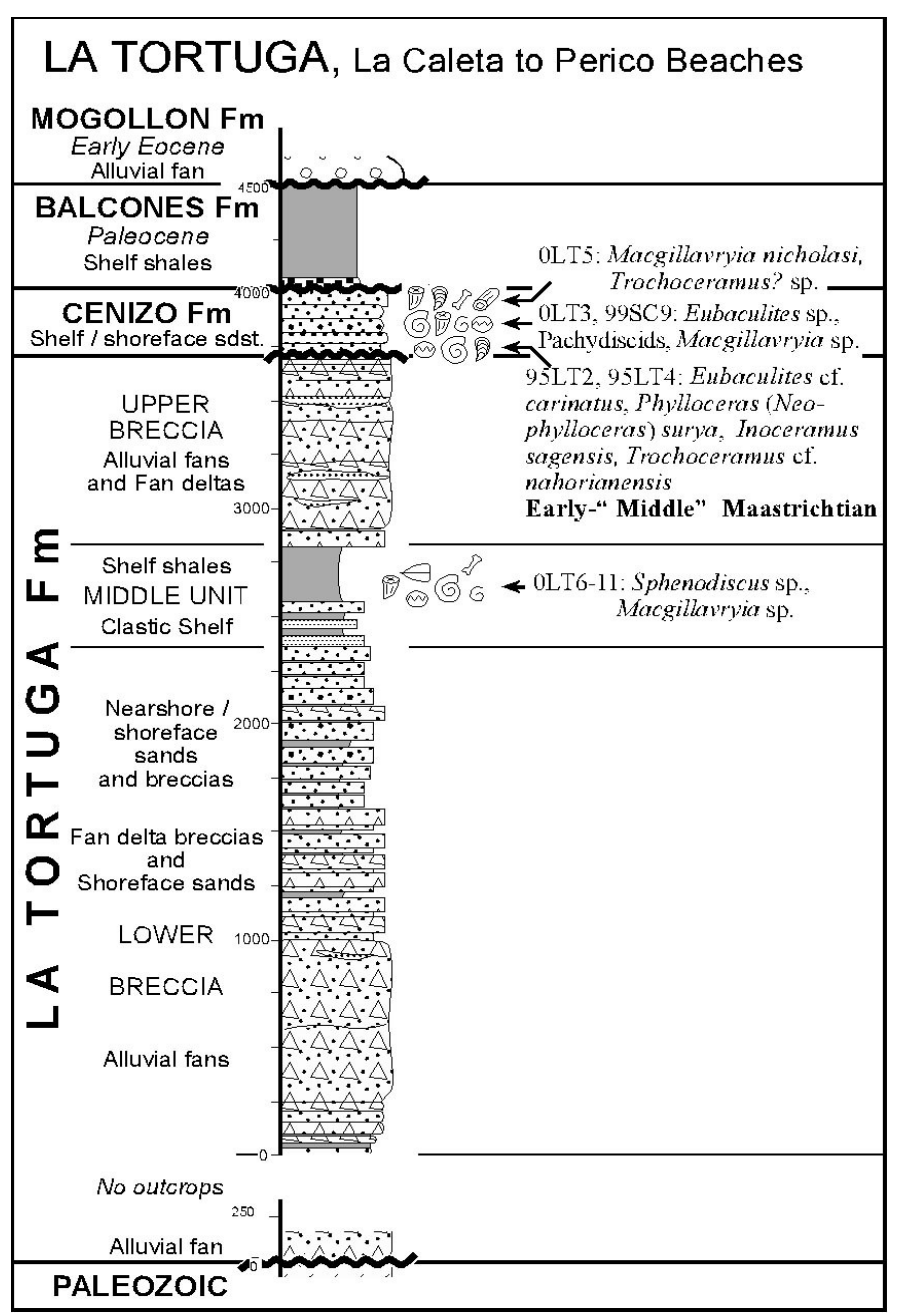

Figure 3. Section of the La Tortuga Formation (Beaches Southwest of La Tortuga, Paita area), and location of rudists. Ammonites and inoceramids are from Jaillard et al. (2003) and Bengtson (written comm.).

\subsection{Cenizo Formation.}

It is formed by a $300 \mathrm{~m}$ thick, clastic dominated succession (Fig. 4), which unconformably overlies the alluvial breccias of the Upper Member of the La Tortuga Formation. The first sequence is represented by the transgressive "Baculites sandstones", which grade upward into black sandstones and breccias of fan delta environment, representing the regressive part of the sequence.

A new transgression is marked by ammonite-bearing, dark sandstones, which locally rest upon the Paleozoic basement, and grade upwards into finer-grained, yellow sandstones of shallow shelf to nearshore environment ("Radiolites sandstones" of Olsson, 1944). The "Radiolites sandstones", more than $100 \mathrm{~m}$ thick, are truncated by a major erosive angular unconformity, which encompasses the Maastrichtian / Paleocene boundary.

In the Cenizo Formation, rudists are associated with inoceramids and marine reptiles, and overly ammonite-bearing beds (Fig. 4) indicating the lower to middle part of the Maastrichtian (Taipe et al., 2000). Rudists are mainly represented by specimens of Macgillavryia nicholasi (Whitfield). Giant specimens of this species occur at the top of the Formation, just beneath the disconformable Paleocene Balcones Formation. 


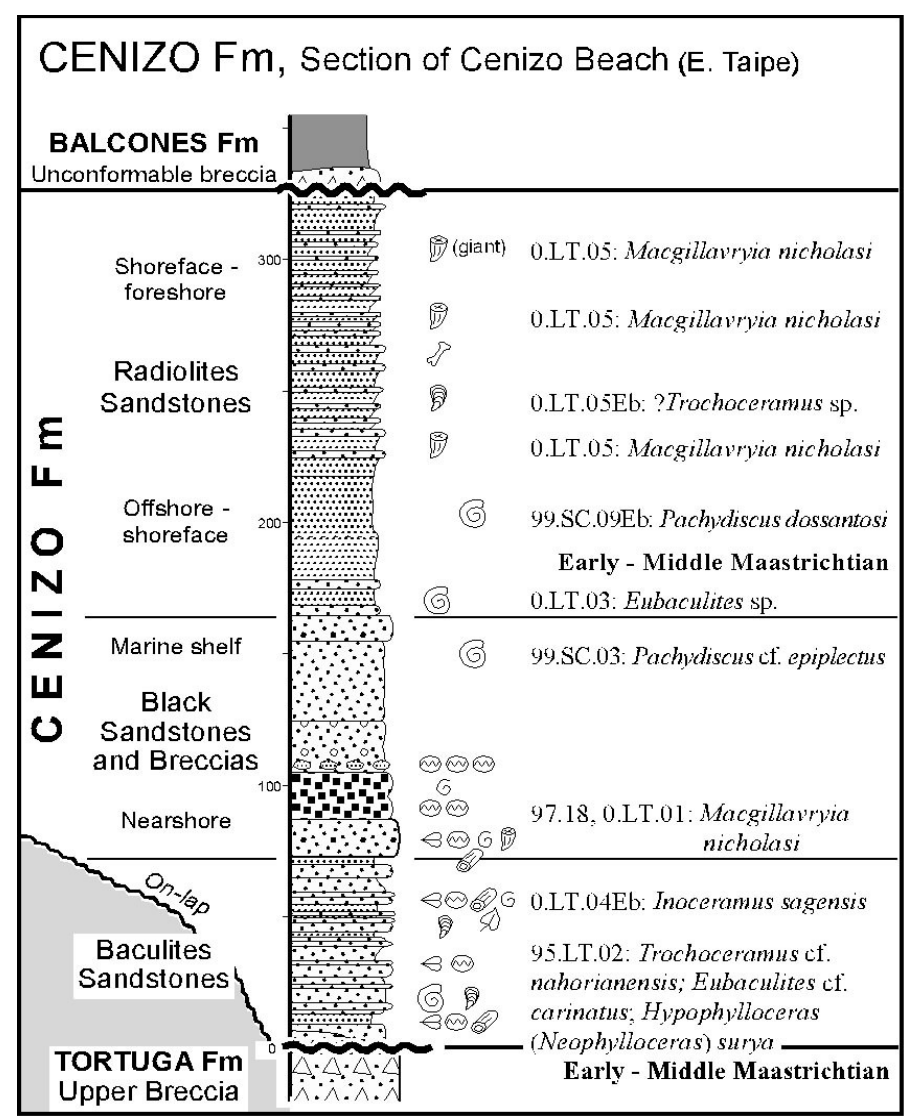

Figure 4. Section of the Cenizo Formation (beaches West of La Tortuga, Paita area), and location of rudist. Ammonites and inoceramids are from Jaillard et al. (2003) and Bengtson (written comm.).

\section{Systematic paleontology}

All the described specimens are housed in the Centre de Sédimentologie Paléontologie, Université de Provence, Marseille.

Family Radiolitidae d'Orbigny 1847

Subfamily Biradiolitinae Douvillé 1902

Genus Macgillavryia Rojas, Itturalde-Vinent and Skelton 1995

Type species Radiolites (Lapeirousia) nicholasi Whitfield 1897

\section{Macgillavryia nicholasi (Whitfield, 1897)}

(Plates 1 and 2)

1897 Radiolites (Lapeirousia) nicholasi Whitfield, p. 186-188, pl. VI-IX.

1934 Sphaerulites (Lapeirousia) cf. nicholasi (Whitfield), Olsson, p. 49-50; pl. 1, fig.2; pl. 8, fig. 4.

1944 Sauvagesia peruviiana, Olsson p. 206-208; pl. 8, figs. 1-5.

1971 Durania nicholasi (Whitfield), Chubb, p. 199-201, pl. 43, fig. 6; pl. 44, fig. 1, pl. 45 fig. 1 ; pl. 46, figs. 1, 2.

1971 Durania nicholasi (Whitfield), Alencaster, p.48, pl. 10, figs 3,4.

1995 Macgillavryia nicholasi (Whitfield), Rojas, Itturalde-Vinent \& Skelton, p. 285288, pl. 3, figs 1-3. 


\section{Material}

It is represented by 6 entire or fragmented right valves (0.LT.5a - d; 0.LT.1; 97.18).

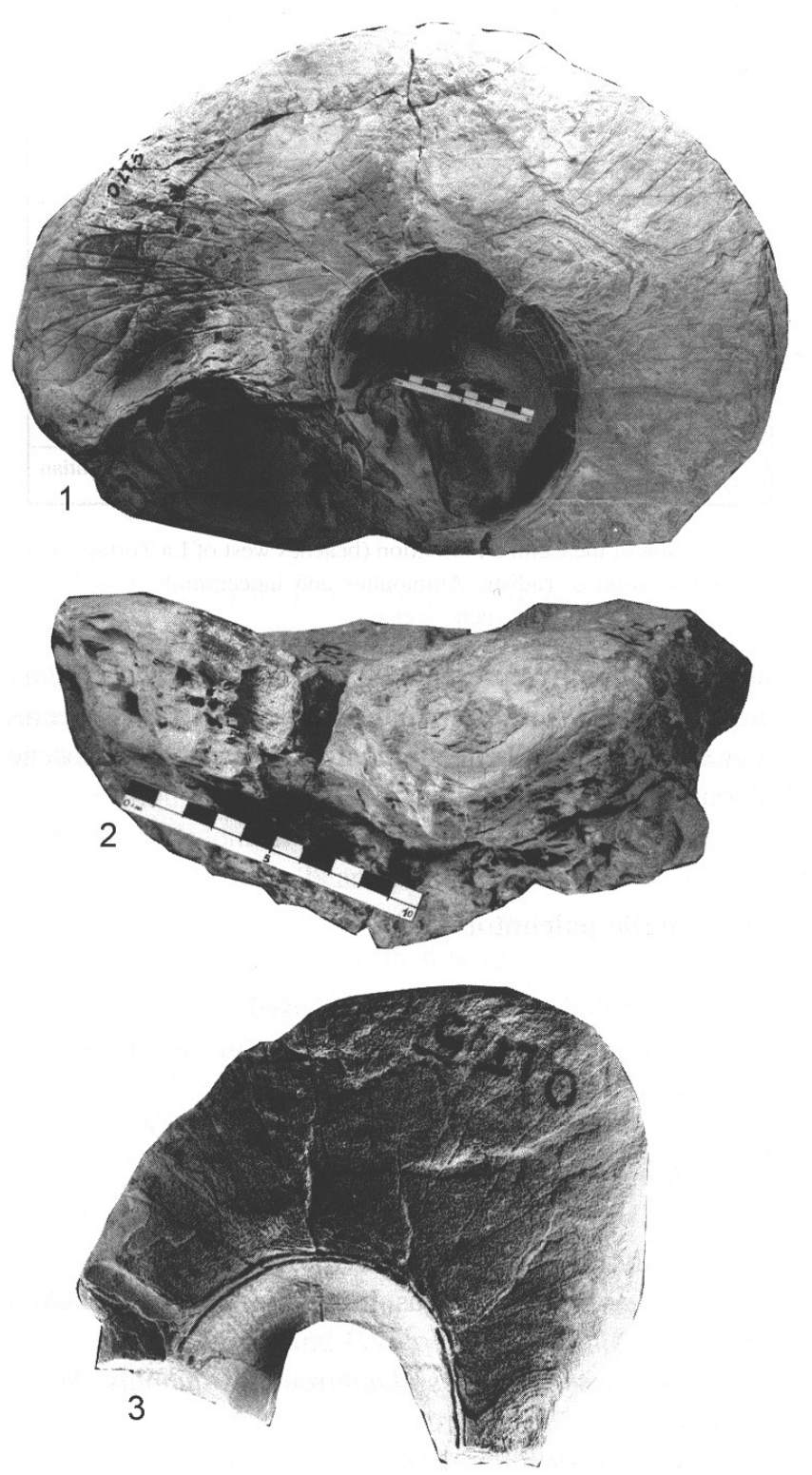

\section{Plate 1}

1.View of the commissural surface of the attached valve of Macgillavryia nicholasi, The diameter of the valve is $60 \mathrm{~cm}$. Note the bifurcated vessels that ornamented the commissural area. The scale bar is $10 \mathrm{~cm}$ long. Specimen 0.LT.5a, Upper part of the Cenizo Formation. Playa Cenizo section.

2. View of the ventral side of an other specimen (0.LT.1) from the Middle part of the Cenizo Formation. Playa Cenizo section.

3. Close-up of the commissural surface of the attached valve of another specimen (0.LT.5c) showing the bifurcated vessels. X 0,75.Upper part of the Cenizo Formation. Playa Cenizo section. 

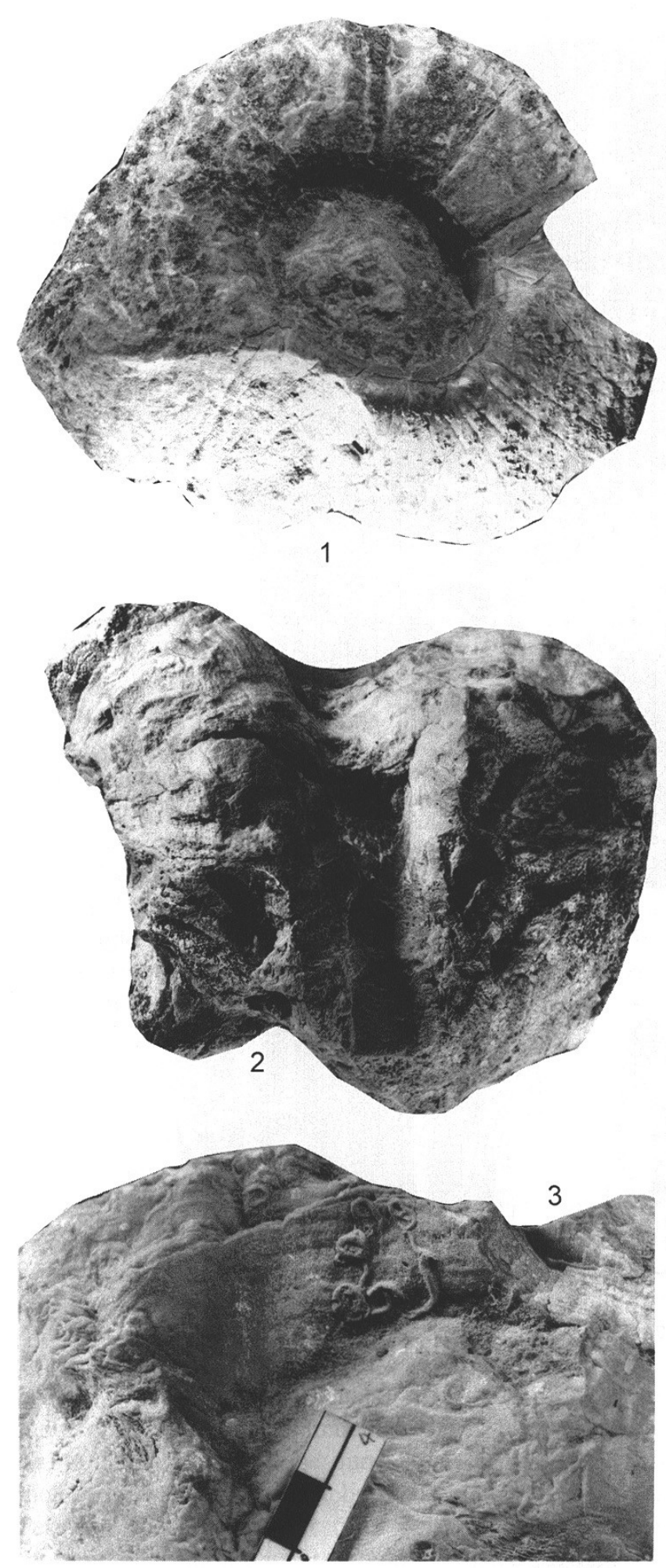

\section{Plate 2}

1. View of the commissural surface of the attached valve of Macgillavryia nicholasi from the lower part of the Radiolites sandstones. Las Playas La Caleta a Perico section. Specimen 97.18. X 0,47.

2. Ventral view of the attached valve of a specimen (0.LT.5b) of Macgillavryia nicholasi showing the depressed smooth subrectangular furrow corresponding to the ventralward band. Upper part of the Cenizo Formation. Playa Cenizo section. X 1.

3. Close-up of encruster organisms (Serpulidae?) on the ventral part of Macgillavryia nicholasi. Specimen 0.LT.1. Middle part of the Cenizo Formation. Playa Cenizo section. X1. 


\section{Description}

Right (attached) valve of large size, depressed conical. Individuals having commonly a diameter of 20 to $30 \mathrm{~cm}$, up to $60 \mathrm{~cm}$ for specimens from top of the Cenizo Formation. Funnel plates thin, largely expanded all around the shell. Cellular network with fine reticulate cells (0,3-0,5 mm.) sometimes subpolygonal or amoeboid. Commissural area large, bearing bifurcated or polyfurcated radial vessels. Radial bands rarely well preserved, corresponding to slight undulations of the outer layer in adult stages of the shell. However, a specimen (0.LT.5b, pl. 2, fig. 2) shows a depressed smooth subrectangular furrow, that probably represents the ventralward $(\mathrm{Vb})$ band. Interband convex, well pronounced. Body cavity conical, extending to the base of the shell. No ligamental ridge. Right valve sometimes encrusted by epibiontic (calcareous Annelids?) organisms (Plate 2, Fig. 3).

Despite the absence of free valve and preservation of the cardinal apparatus, specimens from Peru fit well with descriptions of M. nicholasi from Jamaica (Chubb, 1971) and Cuba (Rojas et al., 1995).

\section{Occurrence}

In the Paita area, M. nicholasi has been collected in the Middle Unit of the la Tortuga Formation where it only is represented by coarse fragments of right valves. Well preserved specimens come from the "Radiolites sandstones". According to Olsson (1934), M. nicholasi should be present in the Early Maastrichtian Monte Grande Formation of the Lancones Basin.

The species is known to accompany both the Campanian Barrettia gigas-multilirata and the Maastrichtian Titanosarcolites giganteus faunas in the Caribbean province (Rojas et al., 1995) and Mexico (Alencaster, 1971).

Genus Biradiolites d'Orbigny 1850

Type species Biradiolites canaliculatus d'Orbigny 1850

\section{Biradiolites cf. jamaicensis Trechmann 1924}

(Plate 3, fig. 3 and 4)

1924 Biradiolites jamaicensis Trechmann, p. 404, pl. 24, figs 5, 5a, 6, 6a, 7.

1971 Biradiolites jamaicensis Chubb, p. 186-187, pl. 35, figs 8-12.

\section{Material}

One individual (LM.26).

\section{Description}

Right valve elongated, of relatively small size (length: $6 \mathrm{~cm}$; diameter: $2,5 \mathrm{~cm}$ ). Outer surface of the shell smooth, bearing nine sharply angular costae separated by angular furrows. Siphonal bands smooth, separated by a broadly costa with a narrow groove down its middle.

\section{Occurrence}

In the Paita area, the specimen comes from the Upper Member of the La Mesa Formation. The species is cited from the Titanosarcolites Limestone of Jamaica ascribed to the Maastrichtian (Chubb, 1971) or the Upper Maastrichtian (Steuber et al., 2002). It also has been found in the Maastrichtian of the Guatemala, upper part of the Ixcoy Formation (Scott, 1995) and El Ceibo section (Fourcade et al., 1997). 


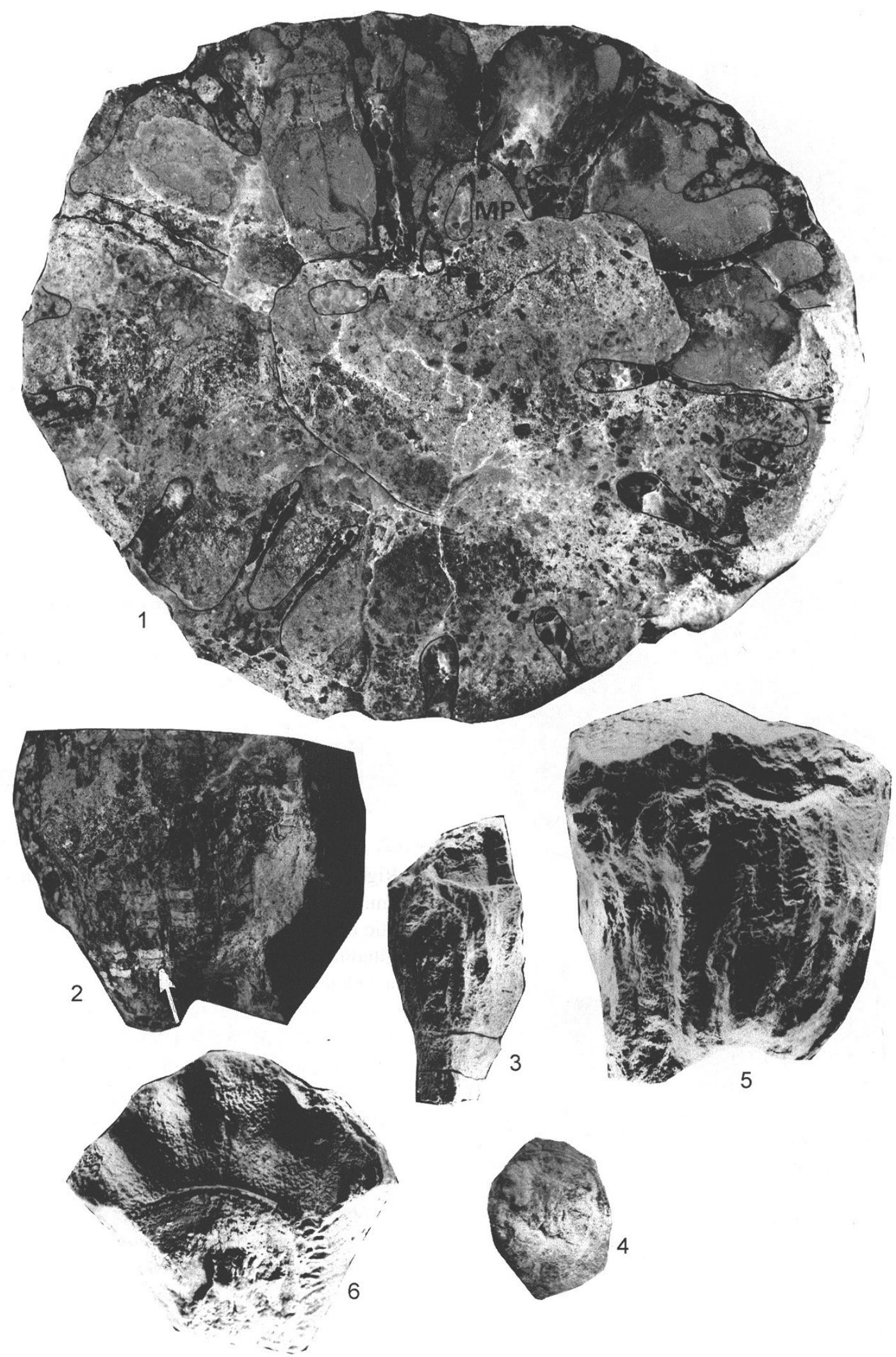

Plate 3

1. Transversal section of the lower valve of Praebarretia sparcilirata. Specimen 97.8A. Upper Member of La Mesa Formation. La Mesa section. X 3,07.

L: ligamental ridge; S, E: pillars; MP: Posterior myophore; P: posterior tooth; A: anterior tooth (nomenclature after Von Dommelen, 1971).

2. Lateral view of the lower valve of the same specimen showing the tabulae (white arrow). X 1.

3. Biradiolites cf. jamaicensis (LM.26). La Mesa Formation Upper Member. La Mesa section. X 1. 
4. Same specimen, transversal section. X 2,3.

5. Radiolites cf. macroplicatus. Lower valve showing the coarse longitudinal costae. Specimen LM.26a. X1. Upper Member of La Mesa Formation. La Mesa section.

6. Radiolites cf. macroplicatus. Commissural surface showing the plications of the commissural surface, characteristic of the species. Specimen LM.26b. X 1. Upper Member of La Mesa Formation. La Mesa section

\author{
Subfamily Radiolitinae \\ Genus Radiolites Lamarck, 1801 \\ Type species Ostracites angeiodes (Picot de Lapeirouse) 1781
}

Radiolites cf. macroplicatus Whitfield 1897

(Plate 3 fig. 5 and 6 )

1897 Radiolites macroplicatus Whitfield, p. 190, pl. 12, fig. 2; pl. 13, fig. 8; pl. 14, figs 1,2 .

1971 Sauvagesia macroplicata (Whitfield), Chubb, p. 196, pl. 41, figs. 1- 4.

1971 Sauvagesia macroplicata (Whitfield), Alencaster, p. 52, pl. 21, figs. 1, 2.

1992 "Radiolites" macroplicatus Whitfield, Alencaster and Pons, p. 327-329; fig. 1; plate 1 , figs. $1-2$.

\title{
Material
}

Eleven weathered fragments of right valves (LM.26a to k).

\section{Description}

Right valve elongate conical. The diameter can reach $10 \mathrm{~cm}$. Commissural surface presenting the plications characteristic of the species. Outer surface ornamented by coarse longitudinal costae corresponding to downfolds of the funnel plates separated by wide angular furrows corresponding to upfolds of the funnel plates. Cells polygonal to subpolygonal are between 0.50 and $1 \mathrm{~mm}$ in diameter. Siphonal bands and ligamental ridge not preserved in our specimens. In radial section, funnel plates appear as forming an angle of about $50^{\circ}$ with the longitudinal axis of the right valve.

\section{Occurrence}

In the study area, $R$. cf. macroplicatus has been found in the Upper Member of the La Mesa Formation It is reported in the literature as a rare species in the Titanosarcolites Limestone from Jamaica, ascribed to the Maastrichtian (Chubb, 1971) and, recently (Steuber et al., 2002), to the Upper Maastrichtian; however, it locally occurs in rock-forming abundance (S.F. Mitchell, written communication). It also has been cited from the Maastrichtian of Chiapas (Alencaster, 1971; Alencaster and Pons, 1992) and from the Maastrichtian of the El Ceibo section in Guatemala (Fourcade et al., 1997).

Family Hippuritidae Gray 1848

Genus Praebarrettia Trechmann 1924

Type species Barrettia sparcilirata Whitfield 1897

Praebarrettia sparcilirata (Whitfield, 1897)

(P1. 3 figs. 1 and 2)

1897 Barrettia sparcilirata Whitfield, p. 245-246, pls 36-37. 
1928 Pironaea peruviana Gerth, p. 235-237, figs. 2-3.

1933 Praebarrettia porosa Palmer, p. 99, pl. 6, figs 3-6. fig. 1.

1971 Praebarrettia sparcilirata (Whitfield) Chubb, p. 215-216, pl. 57, figs 1-2; pl. 58,

1971 Praebarrettia sparcilirata (Whitfield), Van Dommelen, p. 69-75; text-figs 12, 13 (1 to 10), 20, 22; pl. III, fig. 3; pl. IV, figs 1-2.

1971 Praebarrettia sparcilirata (Whitfield), Alencaster, p. 70, pl. 14, fig.1-6, pl.15, fig. 2-3.

\author{
Material \\ Four specimens (97.8 a to d).
}

\title{
Description
}

Keys of determination and morphological nomenclature from Van Dommelen (1971).

Right valves of moderate dimensions; diameter between 50 and $60 \mathrm{~mm}$. Ligamental ridge (L) thick, elongated, with slight constrictions and a rounded tip. Pillar S pediculated, tip (knoll) rounded and thickened. Pillar E with thin pediculate stem and suboval tip. Angle LvE= $107^{\circ} . \mathrm{r} / \mathrm{U}=1 / 3,5$. Myophore (MP) parallel to the axis of $\mathrm{L}$ and projecting on this. Posterior tooth $(\mathrm{P})$ suboval, placed near the tip of the ligamental ridge. Anterior tooth (A) perpendicular to the axis of L. Angle A-P-MP $=140^{\circ}$ (Dentition type B). Rays irregulary alternating: triangular (type 1a, 1b) and elongated no more of one constriction (type 1c); absence of beads. Number of rays: 19-20. Presence of well developed tabulae (pl 3 fig. 2) with interradial extensions forming quadrangular cells between the rays. Mean of space between tabulae: $2 \mathrm{~mm}$ as shown by P. sparcilirata, porosa-type (Van Dommelen, 1971).

A weathered left (free valve) preserved only in one specimen (97.8 a); height about 12 $\mathrm{mm}$; apex central. Typical radial canals covered with a thin, more or less continuous reticulate layer of small pores (0.3-0.5 mm.). Transverse furrows described by Van Dommelen (1971) not observed in our specimens.

Peruvian specimens differ from $P$. corrali (Palmer) by the type of dentition and rays, and the space between the tabulae.

\section{Occurrence}

In the Paita area, the species was collected in the Upper Member of La Mesa Formation. It is known from the Maastrichtian of the Caribbean area: Jamaica (Chubb, 1971; Van Dommelen, 1971), Cuba (Palmer, 1933, Rojas et al., 1995), and Mexico (Alencaster, 1971).

\section{Remark}

Unfortunately, we have not investigated until now the Monte Grande Formation (Upper Campanian-lowermost Maastrichtian?) in the Lancones Basin, from which Olsson (1934) described a multiple-fold hippuritid that he named Orbignya pacifica. The arrangement of rays of this form, figured by Olsson (1934, pl. 8, fig. 1-2) leads to attribute it to the genus Praebarretia, close to the species $P$. corrali Palmer.

\section{Discussion}

As generally demonstrated (e.g. Philip, 1998), rudists are excellent biostratigraphic markers of upper Cretaceous stages and substages. Recent works have refined the biostratigraphy of rudists in using calibrations on ammonites, planktonic foraminifera or strontium isotopic stratigraphy (Steuber et al., 2002). In northwestern Peru, biostratigraphic data drawn from rudists can be compared with those provided by ammonites. 
Three distinct rudist assemblages can be distinguished (Fig. 5):

- the first, the older one, corresponds to the Middle Member (Actaeonella Limestone) of the La Mesa Formation ascribed to the Middle Campanian (Taipe et al., 2000; Jaillard et al., 2003). Rudists are very abundant, but they are unfortunately poorly preserved, due to high energy conditions that prevailed during their deposition. It should be important to attest the existence of the genus Macgillavryia in this unit, because it could be interpreted as a first appearance of the genus in the American domain, although younger than the appearance of the genus in the Arabian domain, where Macgillavryia is reported from the Lower Campanian Samhan Formation (Philip, 1999; 2003).

- the second assemblage is better characterized. It is related to the Upper Member of La Mesa Formation dated by Late Campanian ammonites (Taipe et al., 2000; Bengtson, written communication). It is formed by a relatively more diversified association, including $P$. sparcilirata, $B$. cf. jamaicensis and $R$. cf. macroplicatus. If we refer to the distribution of these species in the Caribbean domain, it should be relevant to propose a Maastrichtian age for this unit instead of a Late Campanian one. In Jamaica, P. sparcilirata occurs near the top of the Titanosarcolites series in the Logie Green area (Mitchell and Gunter, 2002), which have been recently dated as Upper Maastrichtian (Steuber et al., 2002). The relative small size of the specimens of $P$. sparcilirata in northwestern Peru could be considered as due to inamical paleoecologic conditions, but also as a chronospecies of small size, ancestor of the Upper Maastrichtian larger sized $P$. sparcilirata of the Caribbean.

\begin{tabular}{|c|c|c|}
\hline \multicolumn{3}{|c|}{ This work } \\
\hline 昰Balcones文 & & Paleocene \\
\hline \multirow{2}{*}{ 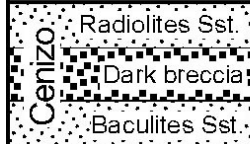 } & \multirow{2}{*}{$\begin{array}{c}\text { 3rd rudist } \\
\text { assemblage }\end{array}$} & Late Maastricht. \\
\hline & & $\begin{array}{l}\text { Early-Middle } \\
\text { Maastrichtian }\end{array}$ \\
\hline O $\triangle$ Up Breccia & & \\
\hline 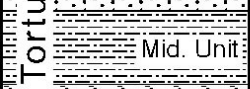 & & $\begin{array}{c}\text { Early } \\
\text { Maastrichtian }\end{array}$ \\
\hline O $\quad$ Low Breccia & & \\
\hline$\because \cup \mathrm{p}$ Conglomerate & & \\
\hline $\begin{array}{lll}0 & 0 \\
0 & 0\end{array}$ & $\begin{array}{l}\text { 2nd rudist } \\
\text { assemblage }\end{array}$ & Late Campanian \\
\hline$E \Sigma \frac{1}{T^{M i d .} \text { Member- }}$ & $\begin{array}{l}1 \text { st rudist } \\
\text { assemblage }\end{array}$ & $\begin{array}{l}\text { Middle } \\
\text { - tol Ite. }\end{array}$ \\
\hline L L M Member & & Campanian \\
\hline & & \\
\hline
\end{tabular}

Figure 5. Rudist assemblages and age assignments proposed in this work.

- the third assemblage fits with the Radiolites sandstones, which constitute the upper part of the Cenizo Formation and contain only one species: Macgillavryia nicholasi. The age of this Formation is well constrained at its base by the occurrence of ammonites (i.e. Eubaculites), which indicates the lower to middle part of the Maastrichtian (Taipe et al., 2000). But the question of the age of the overlying Radiolites sandstones arises. In Jamaica, M. nicholasi occurs up to the Titanosarcolites Limestone, which has been ascribed to the latest Maastrichtian (66-65Ma) by strontium isotope ratios $\left({ }^{87} \mathrm{Sr} /{ }^{86} \mathrm{Sr}\right)$ method (Steuber et al., 2002). 
Therefore, the Radiolites sandstones may be attributed to the Upper Maastrichtian, and the giant forms of Macgillavryia at the top of the formation could represent the youngest rudists in the American province, roughly coeval with those of the Titanosarcolites limestone in the Caribbean area.

\section{Palaeobiogeography}

Comparing the rudist diversity of the Caribbean-American areas as a whole (Fig. 6), it appears that the diversity of Peru-Ecuador is very low with only four genera, none of them being endemic. The impoverishment of the rudist fauna, compared to Cuba, Puerto-Rico, Jamaica or Mexico for instance, could be due to unfavorable environmental and/or climatic conditions in the Peru-Ecuador area, or possibly due to an incomplete sampling.

\begin{tabular}{|c|c|c|c|c|c|c|}
\hline & $\begin{array}{l}\text { Peru-Ecuador } \\
\text { This work }\end{array}$ & $\begin{array}{c}\text { Curaçao-Bonaire } \\
\text { Steuber } 2002\end{array}$ & \begin{tabular}{|c|}
$\begin{array}{c}\text { Puerto Rico } \\
\text { (Steuber } 2002 \text { ) }\end{array}$ \\
Cuba Rojas et al. 1995
\end{tabular} & $\begin{array}{l}\text { Jamaica } \\
\text { Chubb } 1971\end{array}$ & $\begin{array}{l}\text { Guatemala } \\
\text { Steuber } 2002\end{array}$ & $\begin{array}{c}\text { Mexico } \\
\text { Steuber } 2002\end{array}$ \\
\hline GENERA & $\begin{array}{l}\text { Macgillavryia } \\
\text { Biradiolites } \\
\text { Radiolites }\end{array}$ & Durania & $\begin{array}{l}\text { Macgillavryia } \\
\text { Biradiolites } \\
\text { Boumnonia } \\
\text { Durania } \\
\text { Thyrasiylon } \\
\text { Chiapasella } \\
\text { Radiolites } \\
\text { Sauvagesia } \\
\text { Tanpsia } \\
\text { Distefanella }\end{array}$ & \begin{tabular}{|l} 
Macgillavryia \\
Biradiolites \\
Bournonia \\
Durania \\
Thyrastylon \\
Chiapasella \\
Radiolites \\
Sauvagesia \\
\\
Disiefanella \\
Praeradiolites \\
Agriopleura
\end{tabular} & $\begin{array}{l}\text { Biradiolites } \\
\text { Bournonia } \\
\text { Thyrasiylon } \\
\text { Radiolites } \\
\\
\text { Praeradiolites }\end{array}$ & $\begin{array}{l}\text { Macgillavryia } \\
\text { Biradiolites } \\
\text { Bournonia } \\
\text { Durania } \\
\text { Thyrasiylon } \\
\text { Chiapasella } \\
\text { Radiolies } \\
\text { Sauvagesia } \\
\text { Tampsia }\end{array}$ \\
\hline $\begin{array}{cc}\text { Campanian- } \\
\text { Maastrichtian } \\
\text { interval }\end{array}$ & Praebarrelia & $\begin{array}{l}\text { Praebarretia } \\
\text { Hippurites }\end{array}$ & $\begin{array}{l}\text { Praebarrelia } \\
\text { Barrettia } \\
\text { Taccinites } \\
\\
\text { Parasiroma } \\
\text { Torreiles }\end{array}$ & $\begin{array}{l}\text { Praebarretia } \\
\text { Barreltia } \\
\text { Taccinites } \\
\text { Hippurites } \\
\text { Parasiroma } \\
\text { Torreiles? }\end{array}$ & Barreliia & $\begin{array}{l}\text { Praebarrelita } \\
\text { Barrettia } \\
\text { Taccinites } \\
\text { Hippurites }\end{array}$ \\
\hline 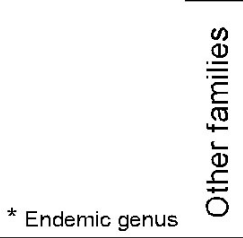 & & & $\begin{array}{l}\text { Tilanosarcolites } \\
\text { Anillocaprina } \\
\text { Plagiopiychus } \\
\text { Miirocaprina }\end{array}$ & $\begin{array}{l}\text { Tilanosarcolies } \\
\text { Anitllocaprina } \\
\text { Plagiopiychus } \\
\text { Mirrocaprina } \\
\text { Monopleura* } \\
\text { Gyropleura* } \\
\text { Anillosarcolites }\end{array}$ & & $\begin{array}{l}\text { Titanosarcolites } \\
\text { Anillocaprina } \\
\text { Plagiopiychus } \\
\text { Coralliochama }\end{array}$ \\
\hline Number of genera & 4 & 3 & 19 & 24 & 6 & 17 \\
\hline Number of species & 4 & 3 & 42 & 59 & 7 & 36 \\
\hline
\end{tabular}

Figure 6. Comparision of rudist genera diversity between the Peru-Ecuador area and other regions of the Caribbean, Central and North America.

A reconstruction of the Campanian-Maastrichtian paleogeographic framework of south America and the Caribbean (Fig. 7) shows that the most diversified rudist-rich areas, encompassing Mexico, Jamaica, Cuba and Puerto Rico, are located around $20^{\circ}$ north latitude, in relatively large shelves with moderate clastic inputs, while rudist areas of Ecuador and northern Peru were located at the Equator and experimented important clastic inputs coming from the South American margin, and possibly relative sea-water heating at this latitude. These adverse paleoenvironmental conditions could explain the rudist low diversity observed in northwestern Peru.

From a palaeobiogeographic point of view, rudist settlement in the Peru-Ecuador areas are probably linked to Campanian and Maastrichtian marine transgressions that dispersed rudist larvae in a large area including: Central America, the Caribbean, Peru and Ecuador.

Three possible routes for inter-provincial exchanges can be proposed:

- one along the Costa Rica-Panama Arc; but few data document this assumption. 
- another route through the oceanic space corresponding to the Caribbean Plate, which was about $800 \mathrm{~km}$ across. This possibility depends on the existence of north-south oceanic surface currents in this area, which have not been documented so far.

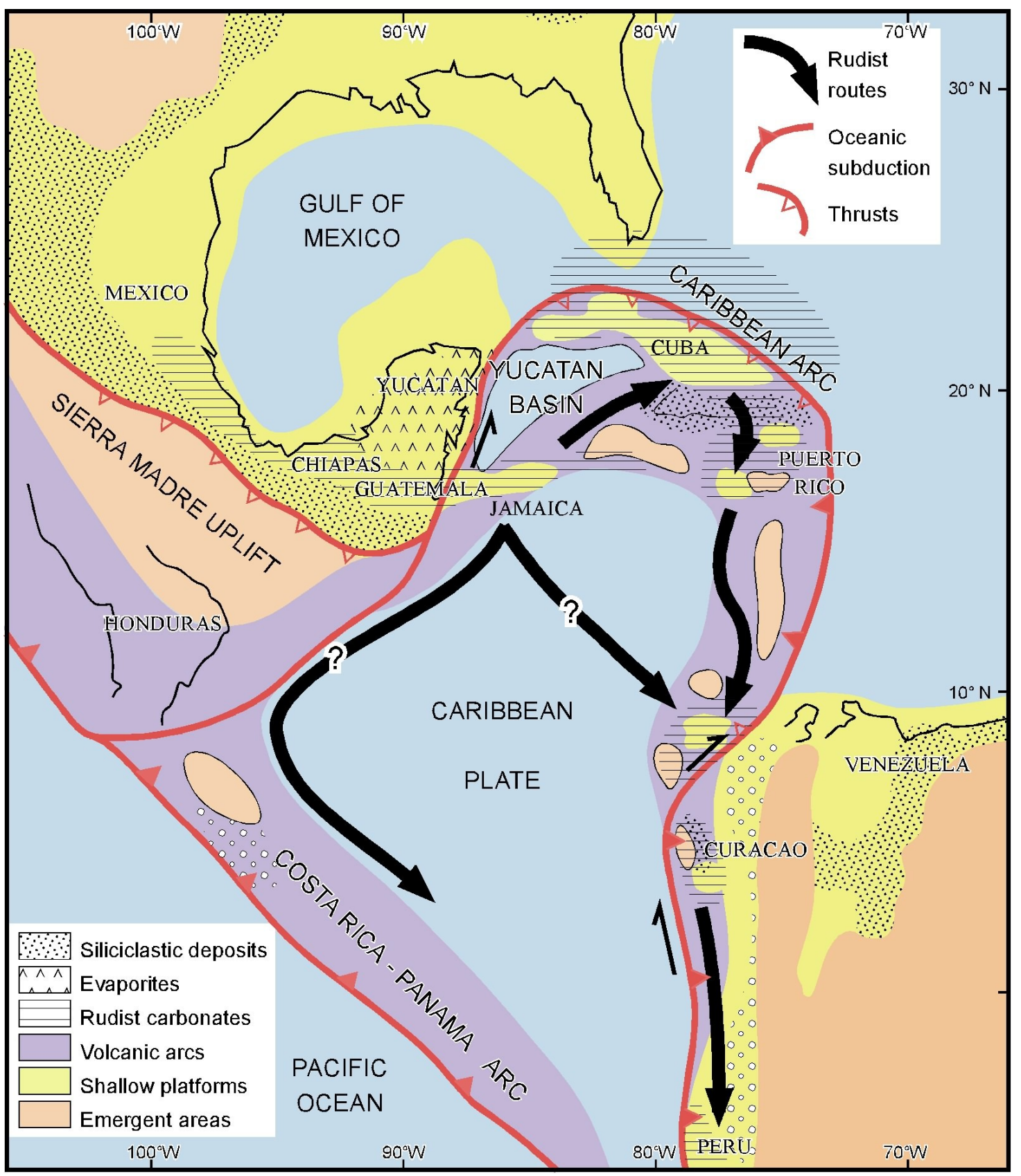

Figure 7. Paleobiogeographic reconstruction of Northwestern South America, Mexico and Caribbean areas during Campanian-Maastrichtian times, showing possible migration routes for rudists (Palaeogeodynamic map after Stephan et al., 1990, Pl. 8, modified).

- the third route could run along the Caribbean arc, then along the Curaçao-Ecuador coast line. The presence of this route is supported by paleobiogeographic stepping-stones established on volcanic highs (i.e. Puerto Rico), where rudist larvae were able to attach and thrive. These paleobiogeographic staging-posts could have played a link between: on one hand the rudist high-diversity areas of North America and the Caribbean, and on the other hand the Peru-Ecuador areas. 
The direction of migration cannot be accurately determined due to a poor knowledge of the oceanic surface circulation in this broad area. However, southward migrations could be inferred, from highly diversified rudist areas (such as Mexico, Cuba, Jamaica), to marginal, poorly diversified areas represented by Ecuador and northwestern Peru at these times.

The genus Macgillavryia has also been recently described (Philip, 1999; 2003) from the Campanian of Oman. Hence, the northwest Peruvian area appears as a new stepping-stone for the trans-Pacific migrations of the genus Macgillavryia between the Caribbean and Oman.

\section{Conclusions}

In northwestern Peru, rudists are present in the La Mesa, La Tortuga and Cenizo Formations, of Middle to Upper Campanian, Lower Maastrichtian, and probably Upper Maastrichtian age, respectively. Three rudist assemblages have been distinguished, characterized by a low diversity, probably related to adverse paleoenvironmental/climatic conditions.

The Peruvian rudist fauna shows palaeobiogeographic affinities with the North American (Mexico) and Caribbean areas. Rudist settlement in northwestern Peru was favoured by Campanian and Maastrichtian marine transgressions, which broadly dispersed rudist larvae, and connected rudist carbonate platforms and submerged palaeohighs (i.e. volcanic islands), where rudists became established.

A palaeobiogeographic route for rudist migrations probably existed along the Caribbean arc and the Curaçao-Ecuador coastline.

New investigations are needed for a better understanding of the paleobiogeographic role played by northwestern Peru and Ecuador areas with respect to migration of ubiquitous rudists (such as Torreites and Macgillavryia) through the Pacific and the Indian Oceans, between the Arabian and American domains, during Santonian, Campanian and Maastrichtian times.

\section{Acknowledgments}

We warmly thank Gloria Alencaster and Simon F. Mitchell for their constructive comments and improvement of the english text. Photographs of rudists are due to J.J. Roccabianca and Axel Arnoux.

\section{References}

Alemán, A., 1999. Late Cretaceous forearc extension in northwestern Peru: Geodynamic implications. $4^{\text {th }}$ International Symposium on Andean Geodynamics-ISAG, Göttingen, 13-16, IRD Publ., Paris.

Alencaster, G., 1971. Rudistas del Cretacico superior de Chiapas. Paleontologia Mexicana 34, Parte I, 91 p., 24 pl.

Alencaster, G., Pons, J.M., 1992. New observations on the upper Cretaceous rudists of Chiapas: comparison between american and european faunas and taxonomic implications. Geologica Romana 28, 327-339.

Chubb, L.J., 1971. Rudists of Jamaica. Palaeontographica Americana, VII (45), 159-257.

Dommelen, H. van, 1971. Ontogenetic, Phylogenetic and Taxonomic studies of the American species of Pseudovaccinites and of Torreites and the Multiple-fold Hippuritids. Thesis University of Amsterdam. $125 \mathrm{p}$.

Fischer, A.G., 1956. Cretaceous of Northwest Peru. International Petroleum Co. Ltd, unpubl. Geological Report WP-13, 72 p. 
Fourcade, E., Alonzo, M., Barrillas, M., Bellier, J.-P., Bonneau, M., Cosillo, A., Cros, P., Debrabant, P., Gardin, S., Masure, E., Philip, J., Renard, M., Rocchia, R., Romero, J., 1997. La limite Crétacé-Tertiaire dans le sud ouest du Peten (Guatemala). Comptes Rendus de l'Académie des Sciences Paris 325, 1, 57-64.

Gerth, H., 1928. Neue faunen der Oberen Kreide mit Hippuriten aus Nord Peru.Leidsche Geologische Medeelingen, Deel 2, Afl. 4, 231-241.

Jaillard, E., Laubacher, G., Bengtson, P., Dhondt, A., Philip, J., Bulot, L.G., Robert, E., 1998. Revisión estratigráfica del Cretáceo superior del noroeste peruano y suroeste ecuatoriano. Datos preliminares, consecuencias tectónicas. Boletin de la Sociedad Geológica del Perú 88, 101-115.

Jaillard, E., Bengtson, P., Dhondt, A., 2003. Late Cretaceous marine transgressions in Ecuador and northern Peru: a refined stratigraphic framework. Journal of South American Earth Sciences, in press.

Olsson, A.A., 1934. Contributions to the Paleontology of Northern Peru: The Cretaceous of the Amotape Region. Bulletins of American Paleontology 20, 69, 1-104.

Olsson, A.A., 1944. Contributions to the Paleontology of Northern Peru Part VII The Cretaceous of the Paita Region. Bulletin of American Paleontology 28, III, 163-305.

Orbigny, A. d', 1842. Voyage dans l'Amérique méridionale, 4, Paléontologie, 1-188.

Palmer, R.H., 1933. Nuevos rudistas de Cuba. Revista de Agricultura, Comercio y trabajo 14, 15-16, 95-125.

Philip, J., 1998. Biostratigraphie et paléobiogéographie des rudistes: évolution des concepts et progrés récents. Bulletin de la Société Géologique de France 169, 689-708.

Philip, J., 1999. Description of well preserved specimens of Macgillavryia, Rojas, Itturalde-Vinent \& Skelton, from the early Campanian of Filim (Eastern Oman): systematics and palaeobiogeographic implications. 5th International Congress on Rudists. Erlanger geol. Abh. Sonderband 3, 53, Erlangen.

Philip, J., 2003. Paleoecological and paleobiogeographical significance of the rudist Macgillavryia chubbii sp. n. in the Campanian of Oman. GeoArabia 8, 1, 129-146.

Rojas, R., Iturralde-Vinent, M., Skelton, P.W., 1995. Stratigraphy, composition and age of Cuban rudist-bearing deposits. Revista Maxicanas de Ciencias geologicas 12 (2), 272-291.

Scott, R.W., 1995. Cretaceous rudists of Guatemala. Revista Mexicanas de Ciencias Geologicas 12, 2, 294-306.

Stéphan, J.F., Mercier de Lépinay, B., Calais, E., Tardy, M., Beck, C., Carfantan, J.-Ch., Olivet, J.-L., Vila, J.-M., Bouysse, Ph., Mauffret, A., Bourgois, J., Théry, J-M., Tournon, J., Blanchet, R., Dercourt, J., 1990. Palaeogeodynamic maps of the Caribbean: 14 steps from Lias to Present. Bulletin de la Société Géologique de France (8) VI, 6, 915-919.

Steuber, T., 2002. A palaeontological database of Rudist Bivalves (Mollusca, Hippuritoidea, Gray, 1848). http://www.ruhr-uni-bochum.de/sediment/rudinet/intro.htm.

Steuber, T., Mitchell, S.F., Buhl, D., Gunter, D., Kasper, H.U., 2002. Catastrophic extinction of Caribbean rudist bivalves at the Cretaceous-Tertiary boundary. Geology 30, 999-1002.

Taipe, E., Jaillard, É., Jacay, J., Pachas, R., Quintana, J., 2000. Ciclos de transgresión marina en la Fm La Tortuga de la serie del Cretáceo superior de Paita $\left(5^{\circ} 20^{\prime} \mathrm{S}\right)$. X Congreso Peruano Geología, Soc. Geol. Perú, Publ. Espec. 2, 54, Lima.

Trechmann, C.T., 1924. The Cretaceous limestones of Jamaica and their Mollusca

. Geological Magazine 61 (9), 385-410.

Whitfield, R.P., 1897a. Descriptions of species of Rudistae from the Cretaceous rocks of Jamaica, West Indies, collected and presented by Mr. F. C. Nicholas. Bulletin of the American Museum of Natural History 9, 185-196.

Whitfield, R.P., 1897b. Observations on the genus Berrettia Woodward, with description of two new species. Bulletin of the American Museum of Natural History 9, 233-246. 